Vol. I No.1 Januari 2018

Rang Teknik Journal

http://joernal.umsb.ac.id/index.php/RANGTEKNIKJOURNAL

\title{
Penerapan Total Quality Management (TQM) Pada Produksi Ready Mix Concrete (Studi Kasus: PT. Igasar Padang)
}

\author{
Utami Dewi Arman \\ Fakultas Teknik dan Perencanaan Jurusan Teknik Sipil, Universitas Putra Indonesia YPTK, \\ Email: udewi2679@gmail.com
}

\begin{abstract}
The rationale for the need for Total Quality Management (TQM) is the best way for companies to compete and excel in global competition by producing high quality products, a continuous improvement effort on human capabilities, processes and environments in accordance with customer needs and satisfaction. To study how the application of Total Quality Management (TQM) in ready mix concrete production in PT. Igasar, a case study was conducted by distributing questionnaires to a few consumers, interviewing staff in production units and other related units and collecting documented written data. The purpose of this study is to identify the extent to which the implementation of Total Quality Management (TQM) in ready mix concrete production process and recommend the theory of application of TQM. The results of this study found that PT. Igasar has not implemented TQM but has implemented Total Quality Control (TQC), which in this case TQC is an element of TQM itself. Based on the results of statistical calculation analysis, in terms of information about the product obtained that $30 \%$ of the number of customers know and use the products from other consumers, $30 \%$ know of the campaign and $40 \%$ know by them. In terms of product delivery schedules, $20 \%$ of customers said it was not late, $70 \%$ said it was sometimes late and $10 \%$ said it was often late, whereas in terms of service, $30 \%$ of customers stated very satisfied with the complaint response, $50 \%$ stated quite satisfied with complaint response and $20 \%$ expressed dissatisfaction with complaint response. From the analysis result, it can be concluded that ready mix concrete products of PT Igasar are considered to meet the specifications and requirements set by the consumer, but in terms of implementation including delivery schedule and service is less satisfactory for consumers.
\end{abstract}

Keywords: controlling, quality, schedule, delivering, ready mix concrete

\begin{abstract}
Abstrak: Dasar pemikiran perlunya Total Quality Management (TQM) adalah cara terbaik agar perusahaan dapat bersaing dan unggul dalam persaingan global dengan menghasilkan produk yang berkualitas tinggi, diperlukan upaya perbaikan berkesinambungan terhadap kemampuan manusia, proses dan lingkungan sesuai dengan kebutuhan dan kepuasan konsumen. Untuk mengkaji bagaimana penerapan Total Quality Management (TQM) dalam produksi ready mix concrete di PT. Igasar, maka dilakukan studi kasus dengan menyebarkan angket kuisioner pada beberapa konsumen, melakukan wawancara kepada staf di unit produksi dan unit yang terkait lainnya serta mengumpulkan data-data tertulis yang telah didokumentasikan. Adapun tujuan dari penelitian ini adalah untuk mengidentifikasi sejauh mana penerapan Total Quality Management (TQM) pada proses produksi ready mix concrete dan merekomendasikan teori penerapan TQM. Hasil dari penelitian ini didapatkan bahwa PT. Igasar belum menerapkan TQM namun telah menerapkan Total Quality Control (TQC), yang dalam hal ini TQC merupakan elemen dari TQM itu sendiri. Berdasarkan hasil analisis perhitungan statistik, dari segi informasi tentang produk diperoleh bahwa $30 \%$ dari jumlah pelanggan mengetahui dan menggunakan produk ready mix concrete dari konsumen lain, 30 $\%$ mengetahui dari promosi dan $40 \%$ mengetahui sendiri. Dari segi jadwal pengiriman produk, $20 \%$ dari pelanggan menyatakan tidak terlambat, $70 \%$ menyatakan kadang-kadang terlambat dan $10 \%$ menyatakan sering terlambat, sedangkan dari segi pelayanan, $30 \%$ dari pelanggan menyatakan sangat puas dengan tanggapan keluhan, $50 \%$ menyatakan cukup puas dengan tanggapan keluhan dan 20 \% menyatakan tidak puas dengan tanggapan keluhan. Dari hasil analisis dapat disimpulkan bahwa produk ready mix concrete dari PT.Igasar dinilai memenuhi spesifikasi dan persyaratan yang ditetapkan oleh konsumen, namun dari segi pelaksanaan termasuk jadwal pengiriman dan pelayanan kurang memuaskan bagi konsumen.
\end{abstract}


Kata kunci: pengendalian, mutu, waktu, pengiriman, ready mix concrete

\section{PENDAHULUAN}

PT. Igasar adalah perusahaan yang didirikan oleh yayasan karyawan PT. Semen Padang pada tanggal 25 januari 1972, dengan tujuan untuk membantu kegiatan PT. Semen Padang terutama dalam bidang sosial, budaya dan ekonomi. Pada tanggal 12 September 1974, yayasan Igasar mendirikan dan mengelola suatu perseroan terbatas yang dinamakan PT. Igasar,dan kemudian pada tahun 1985 usahanya diperluas dengan mendirikan pabrik yang memproduksi ready mix concrete. Dalam melakukan aktifitas perusahaan perlu dirancang suatu sistem untuk merangkai dan mengontrol kegiatankegiatan perusahaan sedemikian rupa sehingga operasi perusahaan dapat berjalan dengan teratur, terkoordinir dan terencana serta dapat diawasi, dimana dengan keberadaan sistem tersebut dapat mengukur sejauh mana sebuah perusahaan dapat mencapai misi yang ada dan memberikan kepuasan kepada pelanggannya. Total Quality Management adalah suatu konsep manajemen modern yang berusaha untuk memberikan respon secara cepat pada tiap perubahan yang ada dan berfokus pada tujuan atau misi perusahaan untuk melayani kebutuhan pelanggan dengan memasok barang dan jasa yang memiliki kualitas setinggi mungkin dan berwawasan lingkungan. Berdasarkan uraian diatas, menarik jika mengkaji sejauh mana penerapan manajemen mutu di PT. Igasar dalam produksi ready mix concrete tersebut.

Adapun tujuan dari penelitian ini adalah untuk mengidentifikasi penerapan Total Quality Management dalam produksi ready mix concrete dan merekomendasikan teori penerapan TQM sebagai usulan perbaikan penerapan manajemen mutu yang telah berjalan. Penelitian ini hanya mencakup tentang penerapan Total Quality Management pada unit kerja produksi dan unit yang terkait pada proses produksi ready mix concrete.

Sistem Kualitas dan Konsep Total Quality Management (TQM) ISSN 2599-2081 Fak. Teknik UMSB
Kualitas menurut standar ISO 9000 merupakan ukuran tingkat untuk kerja dan karakteristik suatu produk barang atau jasa untuk memenuhi fungsi yang diinginkan. Definisi kualitas adalah suatu kondisi dinamis yang berhubungan dengan produk, jasa, manusia, proses, dan lingkungan yang memenuhi atau melebihi harapan, menggunakan kualitas dapat dipandang sebagai tingkat ukuran kemampuan yang memuaskan untuk digunakan ${ }^{1}$. Untuk dapat menghasilkan produk dengan tingkat kualitas yang tinggi, penyedia barang dan jasa konstruksi harus mengikuti selera konsumen yang selalu berubah. Penyedia harus selalu mengadakan penyesuaian baik atas metode, proses, organisasi, fasilitas pendukung dan lain-lain. Suatu proses produksi barang atau jasa tidak dapat begitu saja dirubah misalnya untuk melakukan penyesuaian hasil akhir.

Dalam pengendalian mutu produk antara pemakai (user) dan penyedia (supplier) membuat suatu persetujuan bersama tentang spesifikasi yang harus dipenuhi penyedia agar produk tersebut dapat diterima konsumen. Persoalan datang dengan kemungkinan berubahnya selera konsumen yang berakibat spesifikasi desain serta berlanjut ke manual kerja proses produksi akan menghasilkan produk yang kurang sesuai dengan keinginan konsumen. Dengan demikian selera konsumenlah yang menentukan kualitas mana yang terbaik yang hendak diikuti penyedia produk yang ditawarkan. Berikut ini diuraikan beberapa sistem kualitas antara lain ${ }^{2}$;

1.Quality Control (QC) - Pengendalian mutu Merupakan inspeksi pemisahan produk yang memenuhi dan tidak memenuhi spesifikasi, produk yang gagal dibuang dan sebagian lagi didaur ulang guna menghilangkan ketidaksesuaian produk. Secara singkat sistem pengendalian mutu dapat dilihat pada gambar 1 dibawah ini.
1 Tjiptono, Fandy dan Anastasia Diana, 2001, Total Quality Management, Edisi Revisi, Penerbit Andi, Yogyakarta

2 Materi Workshop, Proyek Peningkatan Pendidikan Sains dan Keteknikan, Direktorat Jenderal Pendidikan Tinggi, Fakultas Teknik, Universitas Hasanuddin, Buku Pertama. 


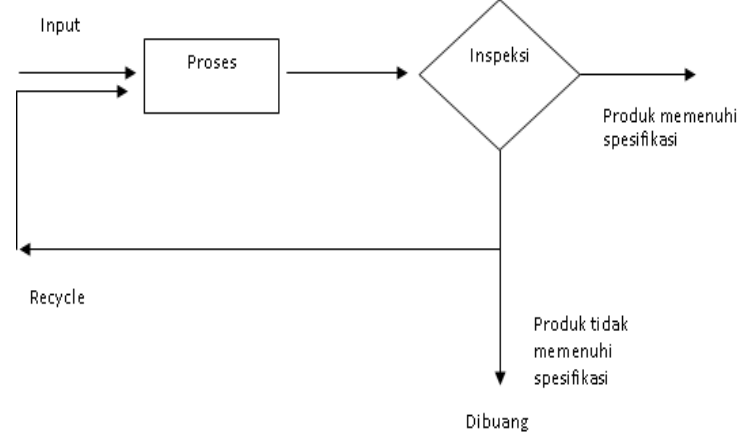

Gambar 1. Diagram Cakupan Sistem Quality Control

(Sumber: Materi Workshop, Universitas Hasanuddin, Buku Pertama)

2.Quality Assurance (QA) - Pemastian Mutu Merupakan proses produksi yang dilaksanakan secara konsisten yang dimulai dari desain, pasokan bahan produk, tata cara proses inspeksi, dan lain-lain, dimana dilakukan sesuai petunjuk manual yang diberikan, direncanakan berdasarkan desain dan spesifikasi produk serta sesuai dengan kebutuhan dan selera konsumen. Proses ini dapat digambarkan pada gambar 2 dibawah ini.

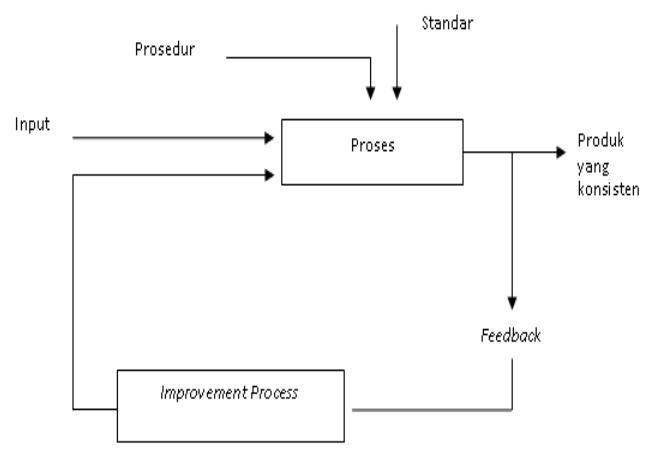

Gambar 2. Diagram Cakupan Sistem Quality Assurance

(Sumber: Materi Workshop, Universitas Hasanuddin, Buku Pertama)

\section{Total Quality Control (TQC) -}

Kesatuan pengendalian mutu

Merupakan suatu sistem manajemen yang dapat mengatur seluruh potensi sumber daya (manusia, teknologi, alat kemampuan teknis dan biaya) sedemikian sehingga di dalam proses kerja terjadi integrasi secara menyeluruh. Keterlibatan semua fungsi dalam kegiatan implementasi TQC adalah sebagai berikut:

a. Keterlibatan semua level dari manajemen puncak sampai karyawan dalam memperhatikan kualitas.

b. Filosofi perbaikan berkesinambungan

c. Orientasi pada pelanggan, dimana kualitas ditentukan dari sudut pandang pelanggan.

Untuk lebih jelasnya proses tersebut diuraikan pada gambar 3 dibawah ini.

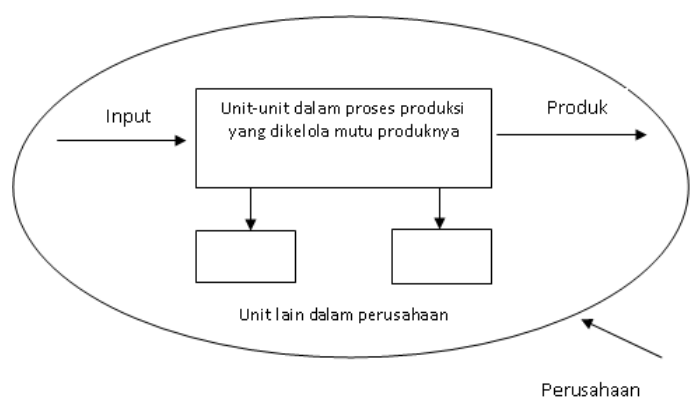

Gambar 3. Diagram Cakupan Total Quality Control

(Sumber: Materi Workshop, Universitas Hasanuddin, Buku Pertama)

\section{Total Quality Management (TQM) -} Kesatuan manajemen mutu

Merupakan suatu pendekatan dalam menjalankan usaha yang mencoba untuk memaksimumkan daya saing perusahaan melalui perbaikan terus menerus atas produk, jasa, manusia, proses dan lingkungannya. Bidang penanganan masalah mutu dan sistem ini juga mencakup hal-hal atau masalah-masalah diluar perusahaan yang mungkin memiliki pengaruh negatif terhadap perusahaan sebagai contoh; perlunya pengolahan limbah hasil produksi yang baik, iklim investasi dan perkembangan situasi, dan penciptaan lingkungan sosial, pendidikan kesehatan disekitar lokasi kegiatan perusahaan. Berikut diuraikan komponen-komponen TQM yang dapat dilihat pada gambar 4 di bawah ini. 


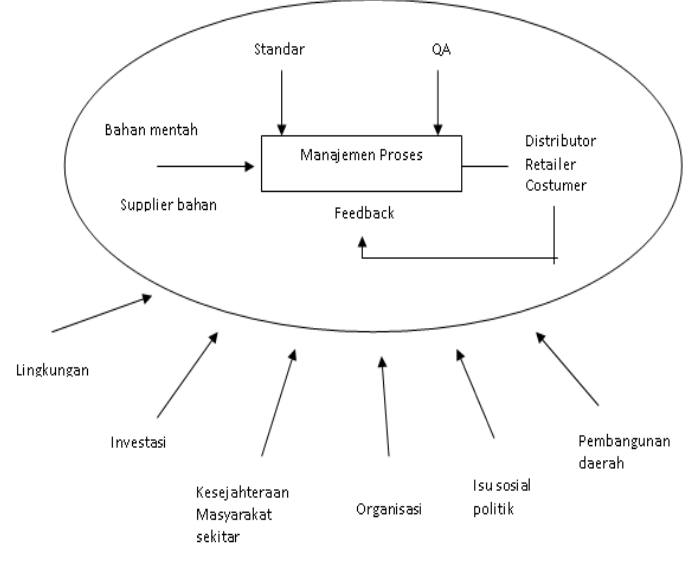

Gambar 4. Diagram cakupan Total Quality Management

(Sumber: Materi Workshop, Universitas Hasanuddin, Buku Pertama)

5.Kaizen - Perbaikan mutu secara terus menerus

Merupakan sistem pengelolaan dan perbaikan yang dilakukan secara terus menerus dalam lingkup aktifitas QC, QA, TQC dan TQM. Ilustrasi dapat dilihat pada gambar 5 di bawah ini.

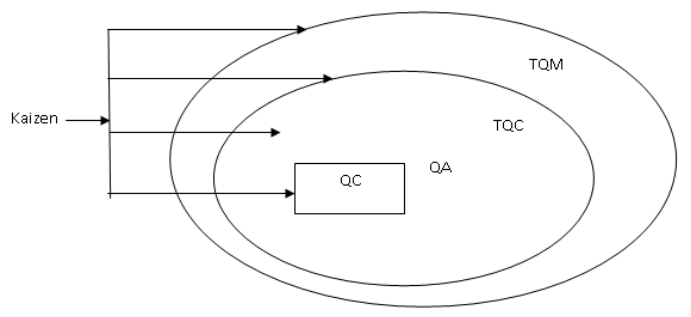

Gambar 5. Diagram Cakupan Sistem Kaizen

(Sumber: Materi Workshop, Universitas Hasanuddin, Buku Pertama)

Ada 8 (delapan) dimensi kualitas yang dikembangkan oleh Garvin dan dapat digunakan sebagai kerangka perencanaan strategis dan analisis pada produk manufaktur yakni; ${ }^{1}$

a) Kinerja (performance) - merupakan karakeristik dari operasi utama dari produk.

b) Ciri-ciri atau keistimewaan tambahan (features) yaitu karakeristik sekunder atau pelengkap

c) Kehandalan (reability), yakni kemungkinan kecil akan mengalami kerusakan atau gagal dipakai.

d) Kesesuaian dengan spesifikasi (conformance to spesifications), yakni sejauh mana karakteristik desain dan operasi memenuhi standar-standar yang telah ditetapkan sebelumnya.

e) Daya tahan (durability), berkaitan dengan berapa lama produk tersebut dapat terus digunakan

f) Serviceability, meliputi kecepatan, kompetensi, kenyamanan, mudah direparasi, penanganan keluhan yang memuaskan.

g) Estetika, yaitu daya tarik produk terhadap panca indera.

h) Kualitas yang dipersepsikan (perceived quality), yaitu citra dan reputasi produk serta tanggung jawab perusahaan terhadapnya.

Menurut Hensler dan Brunell (dalam Scheuing dan Christopher, 1993, pp. 165166), ada empat prinsip utama dalam Total Quality Management (TQM) antara lain; ${ }^{1}$

a) Kepuasan pelanggan - Kebutuhan pelanggan diusahakan untuk dipuaskan dalam segala aspek termasuk; harga, keamanan, dan ketepatan waktu. Semakin tinggi nilai kualitas yang diberikan, maka semakin besar pula kepuasan pelanggan.

b) Respek terhadap setiap orang - Setiap orang dalam suatu organisasi perlu diperlakukan dengan baik dan diberi kesempatan untuk terlibat dan berpartisipasi dalam tim pengambil keputusan.

c) Manajemen berdasarkan fakta Manajemen dalam tim memerlukan data dana analisis statistik sehingga dapat memprediksi hasil dari setiap keputusan dan tindakan yang dilakukan. 
d) Perbaikan berkesinambungan - Setiap organisasi perlu melakukan proses secara sistematis dalam melaksanakan perbaikan berkesinambungan dengan menggunakan konsep siklus PDCA (plan-do-checkaction), dikenal dengan nama siklus Deming yang dikembangkan untuk menghubungkan antara produksi suatu produk dengan kebutuhan pelanggan dan memfokuskan sumber daya semua unit (riset, desain, produksi, pemasaran) dalam suatu upaya kerjasama untuk memenuhi kebutuhan pelanggan tersebut. Beberapa tahapan siklus Deming antara lain ; mengadakan riset pada konsumen dan menggunakannya dalam perencanaan (plan), menghasilkan produk (do), memeriksa produk apakah telah dihasilkan sesuai dengan rencana (check ), memasarkan produk (act), dan menganalisis bagaimana produk diterima di pasar dalam hal kualitas, biaya, dan kriteria lainnya (analyze).

Siklus Deming menurut Garold D. Oberlender dapat diilustrasikan pada gambar 6 di bawah ini. ${ }^{3}$

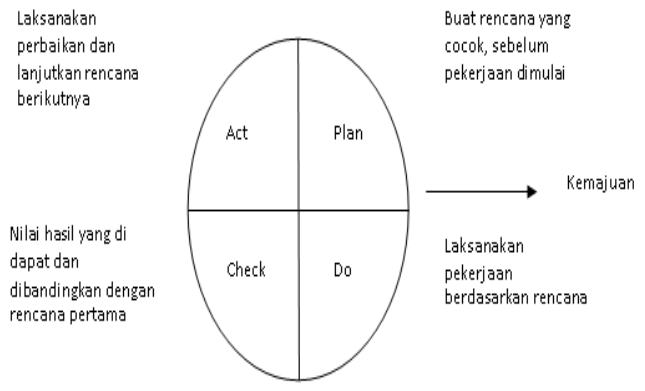

Gambar 6. Siklus Deming menurut Garold D. Oberlender

(Sumber: Project Management For Engineering, Garold D. Oberlender)
Berikut fase-fase implementasi Total Quality Management (TQM) dapat dilihat pada tabel 1 dibawah ini: ${ }^{1}$

Tabel 1. Fase Implementasi Total Quality Management (TQM)

(Sumber: Total Quality Management, Fandy Tjiptono dan Diana Anastasia, 2001)

\begin{tabular}{|c|c|c|}
\hline No & Fase TQM & Uraian \\
\hline 1 & Persiapan & $\begin{array}{l}\text { Membentuk steering } \\
\text { committee (pihak } \\
\text { manajemen yang } \\
\text { bertanggung jawab } \\
\text { dalam penerapan } \\
\text { TQM dalam suatu } \\
\text { perusahaan), } \\
\text { membentuk tim, } \\
\text { pelatihan TQM, } \\
\text { Menyusun } \\
\text { pernyataan visi dan } \\
\text { prinsip sebagai } \\
\text { pedoman,menyusun } \\
\text { tujuan, komunikasi } \\
\text { dan publikasi, } \\
\text { identifikasi kekuatan } \\
\text { dan kelemahan, } \\
\text { identifikasi } \\
\text { pendukung dan } \\
\text { penolak, } \\
\text { memperkirakan } \\
\text { sikap karyawan, } \\
\text { mengukur kepuasan } \\
\text { pelanggan, }\end{array}$ \\
\hline 2 & Perencanaan & $\begin{array}{l}\text { Merencanakan } \\
\text { pendekatan } \\
\text { penerapan TQM, } \\
\text { dalam hal ini } \\
\text { menggunakan siklus } \\
\text { PDCA, identifikasi } \\
\text { proyek, penyusunan } \\
\text { tim, pelatihan tim. }\end{array}$ \\
\hline 3 & Pelaksanaan & $\begin{array}{l}\text { Penggiatan tim } \\
\text { dalam mengerjakan } \\
\text { tugas masing-masing } \\
\text { dengan teknik TQM } \\
\text { yang dipelajari, } \\
\text { memberikan } \\
\text { informasi umpan } \\
\text { balik kepada } \\
\text { Steering Committee, }\end{array}$ \\
\hline
\end{tabular}




\begin{tabular}{|l|l|}
\hline & $\begin{array}{l}\text { umpan balik dari } \\
\text { pelanggan, umpan } \\
\text { balik dari karyawan, } \\
\text { dan memodifikasi } \\
\text { infrastruktur } \\
\text { perusahaan }\end{array}$ \\
\hline
\end{tabular}

\section{Beton (Concrete)}

Beton merupakan suatu kesatuan yang heterogen dan merupakan salah satu bahan konstruksi yang umum digunakan untuk bangunan gedung, jembatan, jalan, dan lainlain. Komponen- komponen beton adalah sebagai berikut; ${ }^{4}$

a. Air - Sebagai media pencampur yang mempunyai kedudukan $8-10 \%$ dalam campuran beton, banyaknya air ditentukan berdasarkan perbandingan air dan semen portland (water cement ratio. Besarnya jumlah air menghalangi proses pengikatan, jika kekurangan air maka reaksi kimia yang terjadi dalam adukan tidak akan selesai. Banyaknya air akan membuat adukan encer, proses pengerjaan mudah, akan tetapi kekuatan beton renda, akan semakin porous dan mudah terjadi segregasi (pemisahan butiran pada adukan). Menurut PBI N.I 2, 1971 persyaratan air sebagai komponen beton adalah ; air tidak boleh mengandung minyak, asam, alkali, garam-garam, bahan organik, sulfat, klorida, atau bahan -bahan lain yang dapat merusak beton, air yang memiliki PH 4,5 -8,5, bahan padat maksimum 2000 ppm, bahan tersuspensi maksimum 2000 ppm, bahan organik maksimum 2000 ppm, dan minyak $2 \%$ dari berat semen, ion sulfat $10.000 \mathrm{ppm}$, ion chlor 10.000 ppm, dan air dapat dipakai apabila mencapai $90 \%$ kekuatan tekan dengan penggunaan air suling pada umur 7 hari dan 28 hari. $^{4}$

b. Semen- Sebagai bahan pengikat dalam campuran beton yang mempunyai kedudukan $12-18 \%$. Semen akan menjadi bahan pengikat hidrolis apabila bercampur dengan air. Bahan baku pembuatan semen adalah sebagi berikut :

1. Batu kapur - mengandung sumber kalsium oksida. Kandungan kalsium oksida didalam batu kapur berkisar 50\% dan bahan ini dalam pengolahan bahan baku semen digunakan sekitar $80 \%$ berat.

2. Batu silica - mengandung sekitar 65 $\%$ oksida silisium, $13 \%$ oksida aluminium dan $70 \%$ oksida besi. Kebutuhan di dalam pengolahan bahan baku semen sekitar $10 \%$ berat.

3. Tanah Liat- mengandung sumber aluminium oksida sekitar $29 \%$ dan oksida besi sekitar $10 \%$. Kebutuhan tanah liat dalam pengolahan bahan baku semen sekitar $10 \%$ berat.

4. Pasir besi - mengandung oksida besi $83 \%$ dan dibutuhkan dalam pengolahan bahan baku semen sekitar $2 \%$ berat.

5. Gypsum-berfungsi sebagai retarder atau bahan yang digunakan untuk memperlambat proses pengerasan awal semen. Kebutuhan gypsum dalam pengolahan bahan baku semen adalah sekiatr $2 \%$ berat.

c. Pasir/Agregat halus - Memiliki kedudukan 30 - $40 \%$ dalam campuran beton. Persyaratan agregat halus/pasir menurut PBI N.I - 2, 1987 adalah sebagai berikut; ${ }^{4}$

- Butir-butir halus, tajam dan keras.

-Tidak pecah atau mudah hancur oleh perubahan cuaca

-Kadar lumpur maksimum $5 \%$ ditentukan terhadap berat kering.

-Bahan organik diperiksa dengan percobaan warna dari Abrams Harder (larutan $\mathrm{NaOH}$ ), dan tidak lebih tua warnanya bila dibandingkan dengan warna standar

-Susunan gradasi agregat mengikuti persyaratan agregat campuran

-Pemakaian pasir laut sebagai agreat halus, harus dengan petunjuk dari lembaga yang berwenang.

${ }^{4}$ G Rani, Iskandar, 1995,Teknoologi Beton, Penerbit FPTK IKIP Padang

${ }^{5}$ Kardiyono, 1998, Hubungan Air Semen dan Kuat Tekan Silinder Beton Dengan Agregat dari Sungai Krasak, Penerbit UGM, Yogyakarta 
b. Kerikil/Split (agregat kasar)

Kerikil/split memiliki kedudukan 40-50

$\%$ dalam campuran beton. Persyaratan

kerikil/split menurut PBI N.I - 2, 1971adalah sebagai berikut: ${ }^{4}$

- Butirnya harus keras dan tidak berpori

- Jumlah butir-butir pipih maksimum 20 $\%$ dari berat agregat seluruhnya, pipih sama dengan panjang yang lebih besar dari tiga kali tebal $(\mathrm{L}>3 \mathrm{t})$

- Tidak pecah/hancur oleh pengaruh cuaca

- Kadar lumpur maksimum $1 \%$

- Tidak mengandung zat reaktif alkali

- Kekerasan butiran diperiksa dengan mesin pengaus Los Angeles dengan kehilangan berat yang diizinkan maksimum $50 \%$

- Susunan gradasi agregat mengikuti persyaratan agregat campuran

- Besar butiran maksimum antara lain 1/5 jarak terkecil antara bidang samping cetakan, 1/3 tebal pelat, $3 / 4$ jarak bersih minimum diantara bidang-bidang tulangan.

\section{e. Admixture}

Admixture adalah bahan serbuk atau cairan yang dibubuhkan ke dalam campuran beton selama, sebelum atau sesudah pengadukan dalam jumlahjumlah tertentu untuk memperoleh beberapa sifatnya. Bahan aditif ini digunakan dengan memperhatikan jumlahnya. Tipe-tipe bahan aditif beton adalah sebagai berikut; ${ }^{4}$

- Accelerating - berfungsi untuk mempercepat waktu pengikatan dan menambah kekuatan awal beton.

- Retarding - berfungsi untuk memperlambat waktu pengikatan beton

- Normal Water Reducing - berfungsi untuk mengurangi jumlah air campuran dengan konsistensi yang ditetapkan.

- Accelerating Water - Reducing, berfungsi untuk mengurangi jumlah air campuran dengan konsistensi yang ditetapkan serta memperlambat waktu pengikatan awal.

- Superplasticizer - berfungsi untuk mengurangi jumlah air campuran dengan konsistensi sangat rendah.
- Air- entrined - berfungsi untuk membentuk gelembung udara dalam campuran beton.

Sifat-sifat beton ditinjau dari segi pemakaiannya adalah; ${ }^{4}$

- Harus memiliki kekuatan tekan yang cukup untuk menahan beban bangunan. Menurut PBI 1971 beton dibagi menjadi beberapa jenis yakni; Beton Kelas I untuk pekerjaan non struktural, Beton Kelas II untuk pekerjaan struktural dengan K-125, K175 dan K-225, Beton Kelas III untuk pekerjaan struktural dengan kekuatan karakteristik yang lebih tinggi dari 225 $\mathrm{kg} / \mathrm{cm}^{2}$.

- Workability - dapat diartikan kemudahan untuk dikerjakan dalam hal ini beton yang dibuat harus mudah untuk dicampur, diangkut dan dipadatkan. Faktor-faktor yang yang menentukan kemudahan pekerjaan beton adalah; gradasi agregat, bentuk partikel, pengaruh kombinasi agregat, pengaruh proporsi campuran, dan kadar air. Alat yang digunakan untuk mengukur workability adalah slump test.

- Kerapatan - adalah ruang atau rongga yang ada pada beton dan diupayakan rongga-rongga tersebut diisi oleh agregat dan pasta semen. Kerapatan merupakan salah satu kriteria untuk beton-beton yang kedap air, beton untuk keperluan atap, lantai reservoar,dsb.

- Kekekalan bentuk (durability) dimana beton tidak boleh mengalami pengembangan dan penyusutan yang menimbulkan retak-retak rambut yang akan menjadi pecah setelah beton mengeras.

Faktor-faktor yang mempengaruhi kekuatan beton adalah;

1. Jenis semen dan kualitasnya - Jenis semen dan kualitasnya sangat mempengaruhi kekuatan rata-rata dan kuat tekan batas beton.

2. Faktor sifat agregat - Pemakaian agregat yang bebas dari kotorankotoran dan zat-zat yang dapat merusak beton. Agregat berupa batu pecah atau split akan menghasilkan 
beton dengan kekuatan tekan yang lebih besar daripada menggunakan agregat alami dari sungai. ${ }^{5}$ Gradasi butiran berpengaruh pada beton basah diantaranya adalah mempengaruhi air pencampur, jumlah semen, pengecoran, dan pemadatan. Sedangkan untuk beton keras akan mempengaruhi sifat kedap air dan sebagainya. Berat jenis agregat berpengaruh pada kekuatan beton. Semakin tinggi berat jenis beton maka semakin tinggi pula kuat tekan beton yang dihasilkan.

3. Faktor air semen - Suatu angka perbandingan berat air terhadap semen yang terdapat dalam campuran beton. Faktor air semen ini sangat erat hubungannya dengan kekuatan tekan beton.

4. Efisiensi dari perawatan (curing) Perawatan sangat penting pada pengerjaan dilapangan dalam pembuatan benda uji beton.

5. Suhu - Beton yang dirawat pada suhu yang lebih tinggi maka kecepatan kenaikan kekuatan tekannya menjadi lebih cepat, akan tetapi pada akhirnya kekuatannya lebih rendah.

6. Umur - Semakin bertambahnya umur beton maka bertambah pula kekuatan tekan beton.

\section{METODE PENELITIAN}

Penelitian dilakukan di PT. Igasar, diketahui bahwa sistem manajemen mutu yang diterapkan adalah masih menggunakan Total Quality Control (TQC) yang dilaksanakan secara menyeluruh terhadap semua unit kegiatan termasuk uni produksi ready mix concrete. TQC masih merupakan elemen dari TQM itu sendiri.

Berikut dijelaskan beberapa tahapan yang dilakukan selama penelitian berlangsung adalah;

a. Melakukan peninjauan pustaka dengan memahami teori dasar dan fase implementasi Total Quality Management (TQM).

b. Mengumpulkan data-data dokumentasi terkait data perusahaan, penerapan sistem manajemen mutu yang mencakup pembentukan tim, perumusan target dan strategi perusahaan serta pelaksanaan penerapan manajemen mutu dalam proses produksi ready mix concrete.

c. Menyusun format kuisioner dan kemudian menyebarkannya kepada kontraktor-kontraktor pengguna ready mix concrete dari PT. Igasar. Dalam hal ini dipilih 10 kontraktor yang pernah menjadi pelanggan PT.Igasar. Kuisioner terdiri dari 17 pertanyaan dan dibagi menjadi 3 (tiga) bagian antara lain; bagian umum, bagian mutu dan bagian pelaksanaan. Bagian umum meliputi; halhal yang berkaitan dengan produk, harga, kegunaan ready mix concrete, ketepatan waktu dan alasan yang diberikan jika terjadi keterlambatan. Bagian mutu meliputi ; hal-hal yang berkaitan dengan keluhan konsumen terhadap mutu ready mix concrete, produk yang ditolak dan standar mutu yang digunakan, sedangkan bagian pelaksanaan mencakup hal-hal yang berkaitan dengan proses pengiriman dan kepuasan pelanggan dalam pelayanan PT. Igasar.

d. Berdasarkan data yang diperoleh, maka dilakukan studi penerapan TQC pada unit kegiatan produksi ready mix concrete di PT.Igasar.

e. Selanjutnya menganalisa data dokumentasi dan data kuisioner serta membandingkan TQC yang diterapkan oleh PT. Igasar dengan teori implementasi TQM.

\section{HASIL DAN PEMBAHASAN}

Berdasarkan studi yang telah dilakukan maka ditemui bahwa PT. Semen Padang belum mencapai konsep TQM. Pada tahun 1984 PT Semen Padang selaku perusahaan induk mulai memperkenalkan sistem manajemen TQC pada unit-unit kerja dan Anak Perusahaan Lembaga Penunjang (APLP) termasuk PT.Igasar. Sistem TQC diterapkan melalui beberapa tahapan yaitu pengenalan, pelatihan, dan pelaksanaan dengan harapan nantinya terbentuk beberapa kelompok TQC atau yang lebih dikenal dengan nama kelompok Gugus Kendali Mutu (GKM). GKM merupakan suatu kelompok unit kerja yang mengadakan

\begin{tabular}{lll}
\hline ISSN 2599-2081 & Fak. Teknik UMSB & 97
\end{tabular}


pertemuan 1 (satu) kali dalam seminggu pada waktu yang telah ditetapkan bersama seluruh anggota kelompok dengan melakukan kegiatan pengendaliandan perbaikan mutu serta mencari solusi dari permasalahan yang muncul di unit kerja. Konvensi GKM diadakan 1 (satu) kali dalam setahun. GKM dibentuk disetiap unit perusahaan atau di setiap divisi. Untuk divisi produksi terdiri dari 3 (tiga) bagian antara lain;

a. Bagian produksi mencakup ; seksi raw material berfungsi untuk mengkoordinir penyediaan dan kebutuhan material selama mekanisasi produksi, seksi baching plant berfungsi untuk mengawasi mekanisasi produksi, sistem kerja alat serta mengkalibrasi alat sehingga hasi yang diperoleh lebih akurat, seksi pemeliharaan pabrik berfungsi mengawasi proses produksi, pemeliharaan alat dan mengontrol kegiatan yang ada di pabrik.

b. Bagian pengendali mutu mencakup; seksi kendali mutu bertugas mengontrol mutu material dan membuat evaluasi hasil pemeriksaan sampel guna mendapatkan komposisi mix design yang disyaratkan, seksi penelitian labor berfungsi memeriksa material baik sebelum maupun setelah proses produksi.

c. Bagian transportasi mencakup, seksi angkutan truk dan angkutan semen curah.

Di awal tahun 1999, penerapan TQC tidak direalisasikan lagi dilingkungan perusahaan, karena tidak adanya inisiatif dari pihak manajemen puncak untuk menggiatkan kegiatan GKM. Sampai saat ini, untuk menjamin mutu pelaksanaan produksi ready mix concrete PT. Igasar mengacu pada Standar Operating Prosedur (SOP).

\section{Pelaksanaan Konsep Total Quality Control (TQC) di PT. Semen Padang}

Dalam penerapan konsep TQC, untuk menyukseskan pencapaian rencana kerja dan penetapan anggaran perusahaan maka perlu ditetapkan perumusan program kerja. Berikut kegiatan pokok dalam perumusan program kerja antara lain; a. Kegiatan mengontrol pekerjaan yang sifatnya rutin agar potensi kinerja dari seluruh sumber daya yang ada pada saat posisi awal dapat dipertahankan. Kegiatan ini menggunakan konsep control points dan control check points. Control points merupakan hasil kerja yang direncanakan, sedangkan control check points merupakan faktor-faktor kerja yang mempengaruhi pencapaian hasil kerja.

Pengontrolan terhadap hasil kerja dan faktor kerja yang terdiri dari 2 macam bentuk yakni;

- Standard - besaran spesifik dari suatu sumber daya berupa kapasitas atau besarnya produk dikurang input yang diperlukan. Standar juga berupa standar kualitas bahan dan Standar Operating Prosedur (SOP).

- Plan - Besaran rencana atau sub rencana kerja.

Standard dan plan merupakan wujud dari control point dan check point dinyatakan dalam bentuk numerik seperti; satuan, \% progres pencapaian kerja, jam, kualitas bahan, biaya dan sebagainya. Setiap karyawan mulai dari manajemen puncak sampai dengan karyawan terendah harus memiliki control point yang jelas dan harus mampu menguasai check points nya. Evaluasi control points dan check points dilakukan dengan menggunakan perhitungan statistik.

b. Kegiatan mengontrol pekerjaan yang sifatnya non rutin yang bersifat evaluatif serta dilanjutkan dengan tindakan-tindakan perbaikan sehingga besarnya potensi kinerja dapat ditingkatkan. Kegiatan perbaikan terus menerus ini menggunakan konsep Activity Plan. Konsep activity plan merupakan pelaksanaan kegiatan yang bersifat perbaikan melalui aktifitas yang bersifat evaluatif yang diikuti dengan penerapan dari aktifitas-aktifitas tersebut dan berusaha untuk meningkatkan nilai potensi sumber daya agar lebih baik dari potensi sebelumnya. Pada konsep activity plan dikenal dengan istilah Key Result Area (KRA) yang didefinisikan sebagai 
masalah pokok yang sangat penting diperhatikan karena berpengaruh terhadap keberhasilan tujuan perusahaan. Kegiatan activity plan adalah suatu program kerja yang mencakup tentang; masalah yang dikerjakan, personil yang bertanggung jawab, waktu awal dan akhir pekerjaan dan target penyelesaian yang dicapai. Perumusan activity plan dilakukan melalui sistem cause and effect diagram atau disebut juga dengan diagram sebab akibat digunakan untuk mengidentifikasi dan menganalisis suatu proses atau situasi dan menemukan kemungkinan penyebab suatu masalah terjadi. Berikut faktorfaktor yang sering menjadi sumber masalah dalam penerapan konsep activity plan di lingkungan perusahaan antara lain;

- Faktor atasan, seringnya terjadi ketidakhadiran atasan pada saat konvensi GKM. Tindakan korektif yang dilakukan dalam mencegah masalah ini terjadi adalah atasan harus meluangkan waktu lebih kurang 15 menit untuk hadir pada saat konvensi sehingga memunculkan motivasi terhadap anggota, atasan harus mengapreasiasi pentingnya manfaat keberhasilan pencapaian target oleh GKM, atasan harus mengetahui jadwal pertemuan GKM dan selalu dingatkan sehari sebelum pertemuan dan lebih lanjut membahas hal-hal yang menjadi masalah, merencanakan perbaikan, dan menentukan permasalahan.

- Faktor fasilitator, seringnya tidak tercapai kesepakatan antara fasilitator dan karyawan dalam mencari solusi permasalahan. Tindakan korektif yang dilakukan untuk mencegah masalah ini terjadi adalah fasilitator perlu mengadakan diskusi dengan anggota GKM lainnya, fasilitator perlu menampung semua aspirasi yang disampaikan oleh anggota, fasilitator harus mengevaluasi pendapat semua anggota, dan fasilitator harus memiliki prinsip bahwa perusahaan tdak akan berhasil tanpa dukungan dari bawah.

- Faktor ketidakmerataan penerapan pengendalian mutu dalam semua divisi. Tindakan korektif yang dilaksanakan untuk mencegah masalah ini terjadi adalah pimpinan harus mensosialisasikan tujuan dan manfaat penerapan TQC pada semua divisi, pimpinan menetapkan komitmen bersama antar Biro di lingkungan divisi operasional untuk menentukan target TQC yang bisa dibentuk, saling mengingatkan dari masing-masing divisi, dan memasukkan salah satu anggota dari divisi lain untuk menjadi anggota GKM.

\begin{tabular}{|c|c|c|c|c|c|c|c|c|c|}
\hline $\begin{array}{l}\text { M } \\
\text { at }\end{array}$ & $\begin{array}{l}\mathbf{S} \\
\mathbf{a} \\
\mathbf{t} \\
\mathbf{u} \\
\mathbf{a} \\
\mathbf{n}\end{array}$ & $\begin{array}{l}\text { K- } \\
10 \\
0\end{array}$ & $\begin{array}{l}\mathbf{K} \\
- \\
12 \\
5\end{array}$ & $\begin{array}{l}\text { K- } \\
17 \\
5\end{array}$ & $\begin{array}{l}\text { K } \\
- \\
22 \\
5\end{array}$ & $\begin{array}{l}\text { K } \\
- \\
25 \\
0\end{array}$ & $\begin{array}{l}\mathbf{K} \\
- \\
\mathbf{3 0} \\
\mathbf{0}\end{array}$ & $\begin{array}{l}\text { K } \\
- \\
35 \\
0\end{array}$ & $\begin{array}{l}\text { K- } \\
40 \\
0\end{array}$ \\
\hline $\begin{array}{l}\mathrm{Se} \\
\mathrm{m} \\
\text { en }\end{array}$ & $\begin{array}{l}\mathrm{K} \\
\mathrm{g}\end{array}$ & $\begin{array}{c}22 \\
5\end{array}$ & $\begin{array}{c}25 \\
0\end{array}$ & $\begin{array}{c}31 \\
5\end{array}$ & $\begin{array}{c}35 \\
0\end{array}$ & $\begin{array}{c}38 \\
5\end{array}$ & 41 & $\begin{array}{c}45 \\
0\end{array}$ & $\begin{array}{c}50 \\
0\end{array}$ \\
\hline $\begin{array}{l}\mathrm{Pa} \\
\text { sir }\end{array}$ & ${ }_{3}^{M}$ & $\begin{array}{l}0,7 \\
32\end{array}$ & $\begin{array}{c}0, \\
69 \\
6\end{array}$ & $\begin{array}{c}0, \\
67 \\
6\end{array}$ & $\begin{array}{c}0, \\
65 \\
7\end{array}$ & $\begin{array}{c}0, \\
59 \\
1\end{array}$ & $\begin{array}{c}0, \\
58 \\
0\end{array}$ & $\begin{array}{c}0, \\
63 \\
3\end{array}$ & $\begin{array}{l}0,5 \\
43\end{array}$ \\
\hline $\begin{array}{l}\text { S } \\
\text { pl } \\
\text { it }\end{array}$ & ${ }_{3}^{M}$ & $\begin{array}{c}0,8 \\
11\end{array}$ & $\begin{array}{c}0, \\
77 \\
2\end{array}$ & $\begin{array}{c}0, \\
74 \\
8\end{array}$ & $\begin{array}{c}0, \\
72 \\
9\end{array}$ & $\begin{array}{c}0, \\
80 \\
1\end{array}$ & $\begin{array}{c}0, \\
78 \\
9\end{array}$ & $\begin{array}{c}0, \\
70 \\
1\end{array}$ & $\begin{array}{l}0,7 \\
39\end{array}$ \\
\hline $\begin{array}{l}\text { A } \\
\text { di } \\
\text { tif }\end{array}$ & $\begin{array}{l}\text { li } \\
\mathrm{t} \\
\mathrm{e} \\
\mathrm{r}\end{array}$ & $\begin{array}{l}0,8 \\
33\end{array}$ & $\begin{array}{c}0, \\
93 \\
8\end{array}$ & $\begin{array}{c}1, \\
05 \\
0\end{array}$ & $\begin{array}{c}1, \\
16 \\
7\end{array}$ & $\begin{array}{c}1, \\
28 \\
3\end{array}$ & $\begin{array}{c}1, \\
38 \\
3\end{array}$ & $\begin{array}{c}1, \\
50 \\
0\end{array}$ & $\begin{array}{l}1,6 \\
67\end{array}$ \\
\hline
\end{tabular}

\section{Ready Mix Concrete}

Ready mix concrete adalah beton siap pakai dengan cara mekanisasi sesuai perbandingan berat material yang telah direncanakan. Bahan baku yang digunakan adalah semen tipe I, batu pecah, pasir, air 
yang memenuhi standar dan zat aditif. Proses produksi ready mix concrete di PT. Igasar ada 2 (dua) jenis antara lain;

- Sistem kering (Dry Process) - Pada sistem ini batching plan berfungsi sebagai penimbangan dan pengisian ke truck mixer sedangkan pencampuran dilakukan dalam truck mixer.

- Sistem basah (Wet Process) - Pada sistem ini batching plan berfungsi sebagai tempat pengisian dan penimbangan material juga berfungsi sebagai tempat pencampuran.

Keuntungan penggunaan ready mix concrete adalah;

- Stabil dalam kualitas

- Dapat menyuplay dalam volume besar dengan waktu yang relatif cepat.

- Dalam pengerjaannya tidak membutuhkan tenaga kerja yang banyak.

- Selama proses produksi resiko kehilangan material kecil sekali

- Tidak membutuhkan area yang besar untuk melakukan proses produksi.

- Proses produksi yang relatif singkat sehingga waktu penyelsaian proyek lebih cepat.

Spesifikasi material standar (consume figure) dari produk ready mix concrete yang ditetapkan oleh PT. Igasar dapat dilihat pada tabel 2 dibawah ini.

Tabel 2. Spesifikasi Material Standar Ready Mix Concrete (Sumber: Anonim, 2002)

Skema proses produksi ready mix concrete dapat dilihat pada gambar 7 di bawah ini.

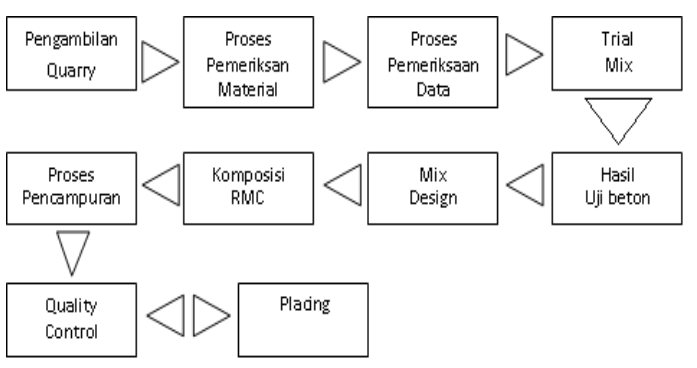

Gambar 7. Bagan Alir Proses Produksi Ready Mix Concrete (RMC)

(Sumber : Anonim, 2002)

\section{Umpan Balik Pelanggan}

Divisi produksi ready mix concrete seharusnya menyadari bahwa untuk memenangkan persaingan pasar PT Igasar harus melakukan perbaikan mutu produk secara terus menerus dengan selalu memperhatikan kepuasan pelanggan. Dalam hal ini peneliti mengidentifikasi umpan balik pelanggan dari segi mutu dan pelaksanaan pengiriman produk.

Berdasarkan hasil kuisioner yang telah disebarkan kepada pelanggan produk ready mix concrete, dari segi informasi tentang produk diperoleh bahwa $30 \%$ dari jumlah pelanggan mengetahui dan menggunakan produk ready mix concrete dari konsumen lain, $30 \%$ mengetahui dari promosi dan $40 \%$ mengetahui sendiri. Dari segi jadwal pengiriman produk, $20 \%$ dari pelanggan menyatakan tidak terlambat, $70 \%$ menyatakan kadang-kadang terlambat dan 10 $\%$ menyatakan sering terlambat, sedangkan dari segi pelayanan, $30 \%$ dari pelanggan menyatakan sangat puas dengan tanggapan keluhan, $50 \%$ menyatakan cukup puas dengan tanggapan keluhan dan $20 \%$ menyatakan tidak puas dengan tanggapan keluhan. Dari hasil ini dapat disimpulkan bahwa produk ready mix concrete dari PT.Igasar dinilai memenuhi spesifikasi dan persyaratan yang ditetapkan oleh pelanggan, namun dari segi pelaksanaan termasuk jadwal pengiriman dan pelayanan kurang memuaskan bagi pelanggan.

Konsep TQC yang diterapkan oleh PT. Semen Padang selaku perusahaan induk dari PT. Igasar diangkat dari ide konsep pengendalian kualitas yang dikemukakan oleh Feigenbaum, 1968 bahwa pengendalian harus dimulai dari perancangan produk dan berakhir hanya jika produk telah sampai ketangan pelanggan yang puas. Komponenkomponen dari konsep TQC adalah; ${ }^{1}$

- Keterlibatan semua fungsi dalam kegiatan kualitas

- Keterlibatan semua karyawan dari manajemen puncak sampai karyawan terendah dalam memperhatikan kualitas

- Filosofi perbaikan berkesinambungan dengan menggunakan siklus Plan-DoCheck-Action (PDCA)

- Orientasi kualitas pada pelanggan kuat. 
Dari hasil penelitian diketahui bahwa produk ready mix concrete dari PT.Igasar dinilai memenuhi spesifikasi dan persyaratan yang ditetapkan oleh pelanggan, namun dari segi pelaksanaan termasuk jadwal pengiriman dan pelayanan kurang memuaskan bagi pelanggan. Untuk memenangkan persaingan pasar dan meningkatkan kualitas perusahaan, peneliti merekomendasikan PT. Semen Padang selaku perusahaan induk untuk mencoba menerapkan konsep Total Quality Management (TQM) baik dilingkungan perusahaan induk maupun dilingkungan APLP, termasuk PT. Igasar.

Kehadiran TQM sebagai paradigma baru yang berusaha untuk memberikan respon secara tepat terhadap setiap perubahan yang ada, baik yang didorong oleh kekuatan internal maupun kekuatan eksternal perusahaan. TQM merupakan salah satu konsep pengendalian mutu yang dapat meningkatkan kemampuan perusahaan untuk bersaing dalam pasar global yang menekannkan kualitas produk dan jasa. Fokus dari konsep TQM ini adalah melayani kebutuhan pelanggan dengan memasok barang dan jasa yang menghasilkan kualitas setinggi mungkin dan berwawasan lingkungan.

Untuk keberlangsungan kemajuan perusahaan, perusahaan sebaiknya tidak hanya memfokuskan pada kekuatan internal perusahaan saja tetapi juga perlu umpan balik dari lingkungan eksternal perusahaan. Secara umum kekuatan-kekuatan eksternal tersebut antara lain; ${ }^{1}$

- Karakteristik demografi dengan tujuan ntuk meningkatkan kesehajteraan masyarakat sekitar perusahaan.

- Kemajuan teknologi, yang memanfaatkan teknologi sebagai sarana untuk meningkatkan produktifitas dan daya saing.

- Perubahan pasar menyesuaikan kebutuhan dan kepuasan konsumen atas barang dan jasa yang dihasilkan.

- Tekanan sosial politik yang dapat mempengaruhi perekonomian secara umum, karena itu diharapkan perusahaan dapat mendeteksi dan merespon perubahan sosial politik yang terjadi diluar perusahaan.

Berikut rekomendasi penerapan TQM yang bisa dilakukan oleh PT.Semen Padang dan APLP (salah satunya PT. Igasar) dalam proses produksi ready mix concrete dapat dijelaskan pada tabel 3 di bawah ini.

Tabel 3. Rekomendasi Penerapan TQM dalam Produksi Ready Mix Concrete di PT. Igasar (Sumber: Anonim, 2002)

\begin{tabular}{|c|c|c|}
\hline $\begin{array}{l}\text { Teori } \\
\text { Fase } \\
\text { TQM }\end{array}$ & $\begin{array}{l}\text { Penerapan TQC } \\
\text { di PT. Igasar }\end{array}$ & $\begin{array}{l}\text { Rekomendasi } \\
\text { Penerapan } \\
\text { TQM di PT. } \\
\text { Igasar }\end{array}$ \\
\hline \multicolumn{3}{|c|}{ Fase Persiapan } \\
\hline $\begin{array}{l}\text { Membe } \\
\text { ntuk } \\
\text { Total } \\
\text { Quality } \\
\text { Steering } \\
\text { Commit } \\
\text { ee }\end{array}$ & $\begin{array}{l}\text { Membentuk } \\
\text { Gugus Kendali } \\
\text { Mutu (GKM) } \\
\text { sebagai tim } \\
\text { penanggung } \\
\text { jawab dalam } \\
\text { pengendalian } \\
\text { mutu masing- } \\
\text { masing divisi. }\end{array}$ & $\begin{array}{l}\text { GKM dapat } \\
\text { dianggap } \\
\text { sebagai } \\
\text { Steering } \\
\text { Committee } \\
\text { dalam } \\
\text { penerapan } \\
\text { konsep } \\
\text { manajemen } \\
\text { mutu. }\end{array}$ \\
\hline $\begin{array}{l}\text { Membe } \\
\text { ntuk tim }\end{array}$ & $\begin{array}{l}\text { GKM untuk } \\
\text { setiap divisi }\end{array}$ & $\begin{array}{l}\text { Membentuk } \\
\text { tim dari } \\
\text { masing- } \\
\text { masing } \\
\text { GKM. Untuk } \\
\text { divisi } \\
\text { produksi, } \\
\text { terdiri dari } 1 \\
\text { GKM dan } \\
\text { beberapa tim } \\
\text { yakni tim } \\
\text { seksi } \\
\text { produksi, tim } \\
\text { seksi } \\
\text { pengendalian } \\
\text { mutu dan tim } \\
\text { seksi } \\
\text { transportasi }\end{array}$ \\
\hline $\begin{array}{l}\text { Pelatiha } \\
\text { n TQM }\end{array}$ & Tidak terstruktur & $\begin{array}{l}\text { Diadakan } \\
\text { pelatihan } \\
\text { TQM berkala }\end{array}$ \\
\hline $\begin{array}{l}\text { Menent } \\
\text { ukan } \\
\text { visi } \\
\text { perubah } \\
\text { an } \\
\end{array}$ & $\begin{array}{l}\text { Merumuskan } \\
\text { filosofi kerja }\end{array}$ & $\begin{array}{l}\text { Menentukan } \\
\text { visi } \\
\text { perubahan } \\
\text { sebagai } \\
\text { pedoman }\end{array}$ \\
\hline
\end{tabular}




\begin{tabular}{|c|c|c|c|c|c|}
\hline \multirow{3}{*}{$\begin{array}{l}\text { sebagai } \\
\text { pedoma } \\
\mathrm{n}\end{array}$} & & & & & \begin{tabular}{|l} 
kuisioner. \\
\end{tabular} \\
\hline & & & \multicolumn{3}{|c|}{ Fase Perencanaan } \\
\hline & & & \multirow{4}{*}{$\begin{array}{l}\text { Merenca } \\
\text { nakan } \\
\text { pendeka } \\
\text { tan } \\
\text { impleme } \\
\text { ntasi } \\
\text { dengan } \\
\text { menggu } \\
\text { nakan } \\
\text { siklus } \\
\text { PDCA }\end{array}$} & \multirow{4}{*}{$\begin{array}{l}\text { Permasalahan } \\
\text { yang ditimbul } \\
\text { dalam suatu } \\
\text { divisi } \\
\text { diselesaikan } \\
\text { oleh GKM } \\
\text { dengan } \\
\text { menggunakan } \\
\text { diagram sebab } \\
\text { akibat dengan } \\
\text { mengidentifikasi } \\
\text { penyebab dari } \\
\text { permasalahan } \\
\text { tersebut dan } \\
\text { membuat } \\
\text { tindakan koratif atas } \\
\text { korektif } \\
\text { permsalahan } \\
\text { tersebut. }\end{array}$} & \multirow{4}{*}{\begin{tabular}{|l}
\multicolumn{2}{l}{ Menggunaka } \\
$\mathrm{n} \quad$ siklus \\
PDCA \\
selama \\
proses \\
produksi dan \\
menggunaka \\
$\mathrm{n} \quad$ diagram \\
sebab akibat \\
untuk \\
mengetahui \\
penyebab \\
permsalahan \\
dan \\
melakukan \\
tindakan \\
korektif.
\end{tabular}} \\
\hline $\begin{array}{l}\text { Menyus } \\
\text { un } \\
\text { tujuan } \\
\text { umum }\end{array}$ & $\begin{array}{l}\text { Merumuskan } \\
\text { tujuan, misi dan } \\
\text { sasaran } \\
\text { perusahaan }\end{array}$ & $\begin{array}{l}\text { Merumuskan } \\
\text { tujuan, misi } \\
\text { dan sasaran } \\
\text { perusahaan }\end{array}$ & & & \\
\hline $\begin{array}{l}\text { Komuni } \\
\text { kasi dan } \\
\text { Publikas } \\
\text { i }\end{array}$ & \begin{tabular}{lr}
\multicolumn{2}{l}{ Mengadakan } \\
rapat antar tim \\
dan konvensi \\
GKM & untuk \\
semua & divisi \\
tidak & rutin \\
(kadang 1 & $\mathrm{x}$ \\
setahun atau $2 \times$ \\
setahun dan \\
kadang tidak \\
diadakan sejak \\
tahun 1999)
\end{tabular} & $\begin{array}{l}\text { Mengadakan } \\
\text { konvensi } \\
\text { berkala dan } \\
\text { publikasi }\end{array}$ & & & \\
\hline \multirow{4}{*}{$\begin{array}{l}\text { Identifik } \\
\text { asi } \\
\text { kekuata } \\
\text { n dan } \\
\text { kelemah } \\
\text { an } \\
\text { Identifik } \\
\text { asi } \\
\text { penduku } \\
\text { ng dan } \\
\text { penolak }\end{array}$} & Analisa SWOT & $\begin{array}{l}\text { Analisa } \\
\text { SWOT }\end{array}$ & & & \\
\hline & & & \multirow{2}{*}{$\begin{array}{l}\text { Identifik } \\
\text { asi } \\
\text { proyek } \\
\text { awal } \\
\text { TQM }\end{array}$} & \multirow[t]{2}{*}{ - } & \multirow{2}{*}{$\begin{array}{l}\text { Perlu } \\
\text { identifikasi } \\
\text { proyek awal } \\
\text { dari } \\
\text { penerapan } \\
\text { TQM }\end{array}$} \\
\hline & $\begin{array}{l}\text { Kurangnya } \\
\text { kepedulian top } \\
\text { manajemen } \\
\text { terhadap } \\
\text { pentingnya }\end{array}$ & $\begin{array}{l}\text { Perlu } \\
\text { identifikasi } \\
\text { pendukung } \\
\text { dan penolak }\end{array}$ & & & \\
\hline & $\begin{array}{l}\text { konsep TQC } \\
\text { untuk kemajuan } \\
\text { perusahaan dan } \\
\text { kurangnya } \\
\text { dukungan top } \\
\text { manajemen } \\
\text { terhadap aspirasi } \\
\text { karyawan bawah }\end{array}$ & & \multirow[t]{2}{*}{$\begin{array}{l}\text { Kompos } \\
\text { isi tim }\end{array}$} & $\begin{array}{l}\text { Divisi Produksi } \\
\text { terdiri dari tim } \\
\text { bagian produksi, } \\
\text { bagian } \\
\text { pengendalian } \\
\text { mutu dan bagian } \\
\text { transportasi }\end{array}$ & $\begin{array}{l}\text { Divisi } \\
\text { Produksi } \\
\text { terdiri dari } \\
\text { tim bagian } \\
\text { produksi, } \\
\text { bagian } \\
\text { pengendalian } \\
\text { mutu dan }\end{array}$ \\
\hline \multirow{4}{*}{$\begin{array}{l}\text { Memper } \\
\text { kirakan } \\
\text { sikap } \\
\text { karyawa } \\
\text { n }\end{array}$} & \multirow[t]{4}{*}{-} & \multirow{4}{*}{$\begin{array}{l}\text { Perlu } \\
\text { identifikasi } \\
\text { sikap } \\
\text { karyawan } \\
\text { dalam } \\
\text { menerapkan } \\
\text { konsep TQM } \\
\end{array}$} & & & $\begin{array}{l}\text { bagian } \\
\text { transportasi }\end{array}$ \\
\hline & & & $\begin{array}{l}\text { Pelatiha } \\
\text { n tim }\end{array}$ & Tidak terstruktur & $\begin{array}{l}\begin{array}{l}\text { Pelatihan tim } \\
\text { berkala }\end{array} \\
\end{array}$ \\
\hline & & & & Fase Pelaksana & \\
\hline & & & $\begin{array}{l}\text { Penggiat } \\
\text { an tim }\end{array}$ & Tidak terstruktur & $\begin{array}{l}\text { Perlu upaya } \\
\text { penggiatan }\end{array}$ \\
\hline \multirow[b]{2}{*}{$\begin{array}{l}\text { Menguk } \\
\text { ur } \\
\text { kepuasa } \\
\text { n } \\
\text { pelangg } \\
\text { an }\end{array}$} & \multirow{2}{*}{$\begin{array}{l}\text { Hanya melayani } \\
\text { komplain } \\
\text { pelanggan dan } \\
\text { merespon }\end{array}$} & \multirow[b]{2}{*}{$\begin{array}{l}\text { Perlu } \\
\text { identifikasi } \\
\text { kepuasan } \\
\text { pelanggan } \\
\text { berkala } \\
\text { dengan } \\
\text { membuat }\end{array}$} & & & tim \\
\hline & & & $\begin{array}{l}\text { Umpan } \\
\text { balik } \\
\text { kepada } \\
\text { steering } \\
\text { commite } \\
\text { e }\end{array}$ & $\begin{array}{lr}\text { Ada } & \text { dilakukan } \\
\text { pada } & \text { konvensi } \\
\text { GKM } & \end{array}$ & $\begin{array}{l}\text { Dilakukan } \\
\text { pada } \\
\text { konvensi } \\
\text { GKM }\end{array}$ \\
\hline
\end{tabular}




\begin{tabular}{|c|c|c|}
\hline $\begin{array}{l}\text { Umpan } \\
\text { balik } \\
\text { dari } \\
\text { pelangg } \\
\text { an }\end{array}$ & Tidak terstruktur & $\begin{array}{l}\text { Perlu umpan } \\
\text { balik dari } \\
\text { pelanggan } \\
\text { berkala }\end{array}$ \\
\hline $\begin{array}{l}\text { Umpan } \\
\text { balik } \\
\text { dari } \\
\text { karyawa } \\
\text { n }\end{array}$ & Tidak terstruktur & $\begin{array}{l}\text { Perlu umpan } \\
\text { balik dari } \\
\text { seluruh } \\
\text { jajaran } \\
\text { karyawan } \\
\text { berkala }\end{array}$ \\
\hline $\begin{array}{l}\text { Memodi } \\
\text { fikasi } \\
\text { infrastru } \\
\text { ktur }\end{array}$ & Tidak tersruktur & $\begin{array}{l}\text { Perlu } \\
\text { modifikasi } \\
\text { infrastruktur } \\
\text { untuk } \\
\text { masing- } \\
\text { masing } \\
\text { divisi. }\end{array}$ \\
\hline
\end{tabular}

\section{SIMPULAN}

1. Berdasarkan penelitian yang telah dilakukan bahwa, PT.Semen Padang, selaku perusahaan induk beserta anak perusahaan dan lembaga penunjang lainnya belum menerapkan konsep TQM namun telah menerapkan konsep Total Quality Control (TQC) untuk semua divisi, termasuk PT. Igasar sebagai salah satu anak perusahaan. Konsep TQC diterapkan dengan membentuk Gugus Kendali Mutu (GKM) yang bertanggung jawab dalam pelaksanaan pengendalian mutu dimana setiap divisi memiliki 1 (satu) GKM. GKM terdiri beberapa tim dan anggota. Permasalahan yang ditimbul dalam suatu divisi diselesaikan oleh GKM dengan menggunakan diagram sebab akibat dengan mengidentifikasi penyebab dari permasalahan tersebut dan membuat tindakan korektif atas permasalahan tersebut.

2. Kegiatan pengontrolan dalam pelaksanaan penerapan TQC adalah kegiatan yang bersifat rutin dan non rutin. Kegiatan yang bersifat rutin diukur berdasarkan standar produk mencakup spesifikasi, proses produksi, dan sebagainya serta rencana kerja dengan menggunakan konsep control points dan check points. Sedangkan kegiatan yang bersifat non rutin dimaksudkan untuk mengevaluasi kegiatan yang telah dilakukan dan mencari tindakan koreksi dari permasalahan yang muncul. Konsep yang digunakan adalah konsep activity plan.

3. Produk ready mix concrete yang diproduksi PT. Igasar dinilai memenuhi spesifikasi dan persyaratan yang ditetapkan oleh pelanggan, namun dari segi pelaksanaan termasuk jadwal pengiriman dan pelayanan kurang memuaskan bagi konsumen.

4. Dalam upaya memajukan perusahaan dan memenangkan persaingan perdagangan untuk perusahaan industri dan manufaktur, PT. Igasar direkomendasikan untuk menerapkan konsep TQM yang mengandalkan kekuatan internal dan kekuatan eksternal dilingkungan perusahaan seperti ; karakteristik demografi di lingkungan perusahaan, pemanfaatan teknologi untuk meningkatkan produktifitas dan daya saing, perubahan pasar serta perubahan sosial-politik.

5. Dalam penelitian ini, peneliti membatasi hanya pada penerapan TQC di PT.Igasar yang dilaksanakan oleh divisi produksi ready mix concrete terkait dalam proses produksi secara umum. Perlu pengembangan penelitian yang menjelaskan tentang quality control dan quality assurance untuk proses produksi ready mix concrete.

\section{UCAPAN TERIMA KASIH}

Segala puji dan syukur penulis haturkan kehadirat Allah SWT yang telah melimpahkan rahmat dan karunia-Nya sehingga penulis dapat menyelesaikan penelitian ini. Penulis juga mengucapkan terima kasih kepada keluarga yang telah memberi dukungan baik materil dan moril, kemudian kepada Bapak (Alm) Ir. Zulkarnain NA, MM dan Bapak Taufika Ophiyandri, $\mathrm{PhD}$ yang telah memberikan arahan dan bimbingan dan tak lupa mengucapkan terima kasih kepada Bapak Ir. Joni Ismail RM, selaku Kabag Pemasaran Non Semen PT. Igasar yang telah meluangkan waktunya, memberikan informasi dan data-data yang diperlukan 
selama penelitian serta keluarga besar administrasi Jurusan Teknik Sipil Fakultas Teknik Universitas Andalas Padang.

\section{REFERENSI}

(1) Tjiptono, Fandy dan Anastasia Diana, 2001, Total Quality Management, Edisi Revisi, Penerbit Andi, Yogyakarta.

(2) Materi Workshop, Proyek Peningkatan Pendidikan Sains dan Keteknikan, Direktorat Jenderal Pendidikan Tinggi, Fakultas Teknik, Universitas Hasanuddin, Buku Pertama.

(3) Oberlender, D, Garold, Project Management For Engineering

(4) G Rani, Iskandar, 1995,Teknoologi Beton, Penerbit FPTK IKIP Padang

(5) Kardiyono, 1998, Hubungan Air Semen dan Kuat Tekan Silinder Beton Dengan Agregat dari Sungai Krasak, Penerbit UGM,Yogyakarta 